\title{
Immunolocalization of cholesterol side-chain-cleavage cytochrome P-450 and 17a-hydroxylase cytochrome P-450 in bovine ovarian follicles
}

\author{
R. J. Rodgers*, H. F. Rodgers $\dagger$, P. F. Hall§, M. R. Waterman $\dagger$ and \\ E. R. Simpson* $+\ddagger$
}

${ }^{*}$ Cecil H. and Ida Green Center for Reproductive Biology Sciences, Departments of $\dagger$ Biochemistry and $\$$ Obstetrics and Gynecology, The University of Texas Health Science Center at Dallas, Dallas,

Texas 75235, and \$The Worcester Foundation for Experimental Biology, Shrewsbury, Massachusetts 01545, U.S.A.

\begin{abstract}
Summary. Follicles were collected from cows and processed for electron microscopy and for immunofluorescent staining at the light microscope level. Key regulatory steroidogenic enzymes cholesterol side-chain-cleavage cytochrome P-450 (P-450 $\left.{ }_{\text {scc }}\right)$ and $17 \alpha$-hydroxylase cytochrome P-450 (P-450 $\left.{ }_{17 \alpha}\right)$ were immunolocalized using specific $\mathrm{IgG}$ fractions raised against these enzymes. In larger follicles in which the theca interna had differentiated, positive staining for cytochromes $\mathrm{P}-450_{\text {scc }}$ and $\mathrm{P}-450_{17 \alpha}$ was observed in the cells of the theca interna. Electron microscopic examination showed that these cells were rich in endoplasmic reticulum, mainly rough, and had moderate numbers of mitochondria with tubular and lamellar cristae. Positive staining was also present in the theca of follicles undergoing atresia. Positive staining for cytochrome $\mathrm{P}-450_{17 a}$ was not observed in the membrana granulosa but cytochrome $\mathrm{P}-450_{\text {scc }}$ was present in the membrana granulosa in some follicles, particularly in the larger antral follicles. By contrast, positive staining for both enzymes was not observed in stroma, surface epithelium or in small preantral follicles in which the theca interna had not differentiated. These results indicate good agreement between the type(s) of steroidogenic enzyme(s) present in tissues and the type(s) of steroid hormone(s) produced. It is concluded that regulation of steroid hormone production involves, at least in part, regulation of the levels of steroidogenic enzymes.
\end{abstract}

\section{Introduction}

During the oestrous cycle of the cow the ovarian production rates of steroid hormones, such as progesterone, androstenedione and oestradiol-17ß, change episodically, and these changes are related to the stage of development of follicles and corpora lutea (see Hansel \& Convey, 1983), and also to the follicular and luteal content of steroidogenic enzymes (Rodgers et al., 1986a). Much of the ovarian androgen and oestrogen is synthesized by the largest, healthiest antral follicle (see Hansel \& Convey, 1983). In the follicle walls there are two distinct zones, theca interna and membrana granulosa, which have been dissected and cultured to determine their steroidogenic capacity in vitro (McNatty et al., 1984a, b).

In these and other similar studies it was not possible to determine in which cell type of the theca interna and membrana granulosa steroid hormones were synthesized, or to control for changes in cell function that may have occurred when the tissues were transferred to an in-vitro situation. To overcome these problems and to establish the cellular localization of steroidogenic enzymes, cholesterol side-chain cleavage cytochrome P-450 ( $\left.\mathrm{P}-450_{\text {scc }}\right)$ and $17 \alpha$-hydroxylase cytochrome P-450 (P-450 $17 \alpha$ ) were immunolocalized in cow follicles at the light microscope level by using specific antisera. Cytochromes $\mathrm{P}-450_{\text {scc }}$ and $\mathrm{P}-450_{17_{\mathrm{a}}}$ are both important regulatory enzymes in the 
steroidogenic pathway and catalyse respectively the conversion of cholesterol to pregnenolone and the conversion of pregnenolone or progesterone into androgens.

\section{Materials and Methods}

Electron microscopy. Reproductive tracts were removed from cows killed at an abattoir within 20 min of death. The ovarian artery was cannulated and the ovary perfused with $35 \mathrm{ml}$ Dulbecco's modified Eagle's medium delivered from a syringe using gentle manual pressure. Each ovary was then perfused with $25 \mathrm{ml}$ ice-cold $2.5 \%$ glutaraldehyde in phosphate buffer $(0 \cdot 1 \mathrm{M}, \mathrm{pH} 7 \cdot 25)$. The ovary was then dissected into smaller pieces containing whole unruptured follicles, and these pieces were further fixed in ice-cold $2.5 \%$ glutaraldehyde. On return to the laboratory, the walls of 6 antral follicles were cut into small pieces and further fixed for $1 \mathrm{~h}$ and then rinsed in phosphate buffer containing $5 \%$ sucrose. Specimens were post-fixed in $2 \%$ osmium tetroxide in distilled water for $1 \mathrm{~h}$ at room temperature, dehydrated in a series of increasing concentrations of acetone and embedded in a mixture of araldite and LX-112 resin (Ladd Research Ind., Inc., Burlington, VT, U.S.A.). Sections cut on a diamond knife were stained with $10 \%$ uranyl acetate in methanol, and in lead citrate, and examined in a Philips EM 301 electron microscope. Thick sections $(1 \mu \mathrm{m})$ for light microscopy were cut on glass knives and stained with $1 \%$ methylene blue.

Tissues for immunostaining. Ovaries from the same source as above were collected and cut into smaller pieces and the location and sizes of follicles within each piece were recorded. Tissues were embedded in O.C.T. compound (Miles Scientific, Naperville, IL, U.S.A.) on solid $\mathrm{CO}_{2}$. In some instances the follicular fluid was gently expressed from large follicles $(>15 \mathrm{~mm})$ and the cavity refilled with O.C.T. compound before freezing on solid $\mathrm{CO}_{2}$. Tissues were stored at $-70^{\circ} \mathrm{C}$ until the day of staining. In this study 15 ovaries each from different animals comprising more than 25 follicles, of at least $3 \mathrm{~mm}$ in diameter, and numerous smaller follicles were examined.

Immunofluorescent staining. Frozen sections were cut on a cryostat, and then allowed to air-dry on glass slides at room temperature for $5 \mathrm{~min}$. Sections for histological examination were cut from each block and fixed in $5 \%$ formalin in phosphate-buffered $(0.1 \mathrm{M}, \mathrm{pH} 7 \cdot 4)$ saline, and subsequently stained with haematoxylin and eosin $(\mathrm{H} \& \mathrm{E})$. Other sections for immunostaining were rinsed in phosphate-buffered saline containing $0.5 \%$ Triton-X100 $(3 \times 5 \mathrm{~min})$ and all further incubations and rinses were carried out in this buffer. The sections were incubated with primary rabbit immunoglobulin (IgG; $100 \mu \mathrm{g} / \mathrm{ml}$ ) for $1 \mathrm{~h}$ at room temperature in a humidified atmosphere, rinsed $(3 \times 5 \mathrm{~min})$, further incubated with a secondary goat anti-rabbit IgG conjugated with fluorescein isothiocyanate (Cappel Affinity Purified Antibodies, Cooper Biomedical, Malvern, PA, U.S.A.), rinsed again $(3 \times 5 \mathrm{~min})$ and mounted with glycerol/phosphate-buffered saline $(9: 1, \mathrm{v} / \mathrm{v})$ under a glass coverslip. Sections were examined and photographed with an Olympus BH microscope with appropriate barriers and filters for fluorescence and photographed with Kodak Tri-X pan film (exposure time $1 \mathrm{~min}$ ). To facilitate the comparisons of the intensities of immunostaining all prints in this manuscript of immunostained sections were developed on the same grade paper and exposed for the same period of time.

On any one day of staining follicles of various sizes were examined and appropriate control incubations, without primary IgG or with non-immune IgG, were carried out for each ovary.

Antisera. Cytochrome P-450 sce $_{\text {wa }}$ was puried from bovine adrenal cortex (Seybert et al., 1979) and kindly donated by Dr J. D. Lambeth, Emory University, Atlanta, GA, U.S.A. An IgG fraction was raised against cytochrome $\mathrm{P}-450_{\text {sec }}$ in rabbits and prepared as described previously (DuBois $e t$ al., 1981). Cytochrome $\mathrm{P}-450_{17 a}$ was purified from pig testis and IgG raised against it in rabbits (Nakajin \& Hall, 1981). It has been shown previously by Western immunoblot analyses that the IgGs react specifically with their respective cytochrome P-450 enzymes and do not cross-react to any significant degree with other proteins of bovine follicles (Rodgers et al., 1986a). 


\section{Results}

Electron and light microscopic examination of ovarian follicles

The ovarian tissues and cell types examined for the presence or absence of cytochromes $\mathrm{P}-450_{\text {scc }}$ and $\mathrm{P}-450_{17 \alpha}$, steroidogenic enzymes of the inner-mitochondrial membrane and endoplasmic

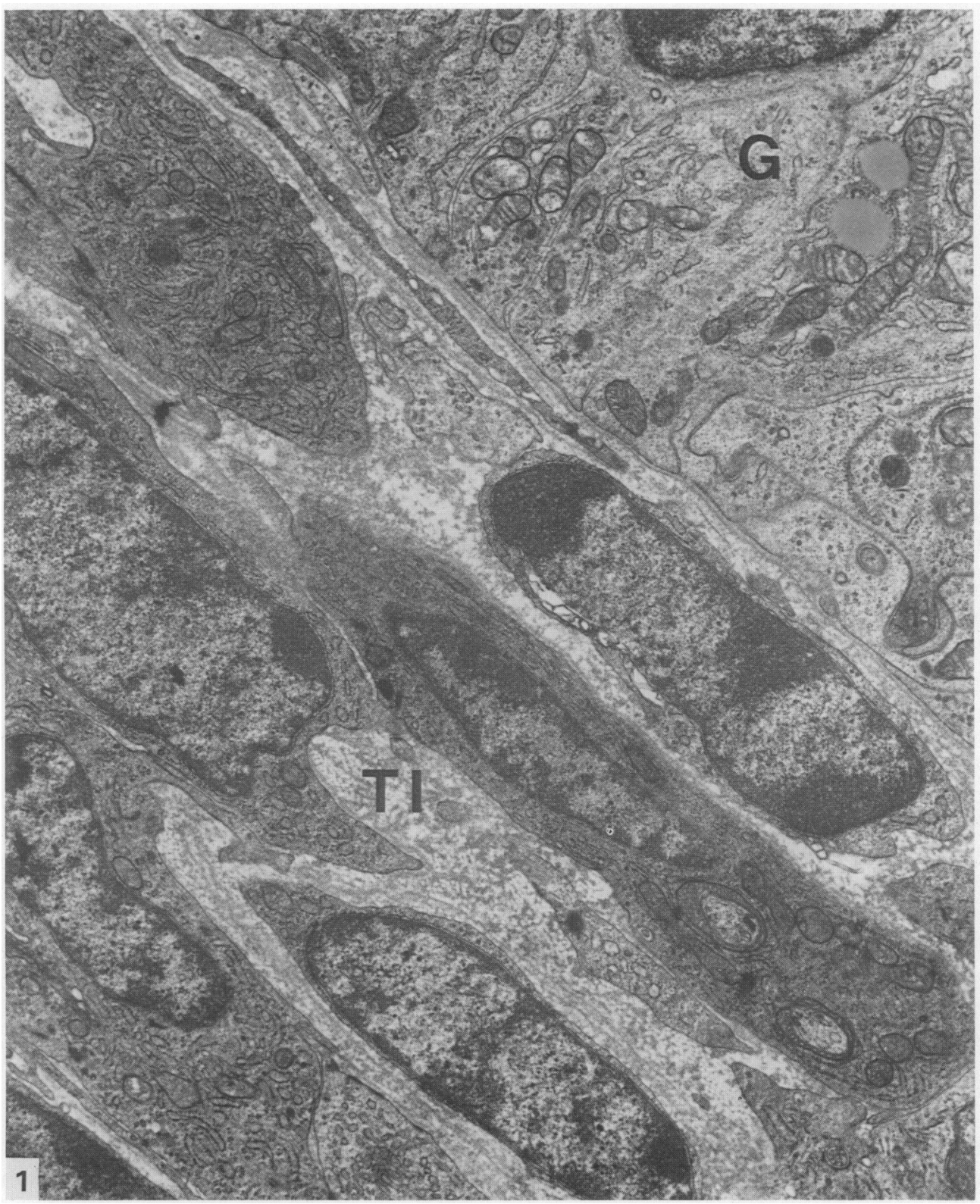

Fig. 1. Electron micrograph of a follicle wall ( $5 \mathrm{~mm}$ follicle) showing the cells of the theca interna (TI) which have much rough endoplasmic reticulum, and cells of the membrana granulosa $(\mathrm{G}) . \times 12800$. 

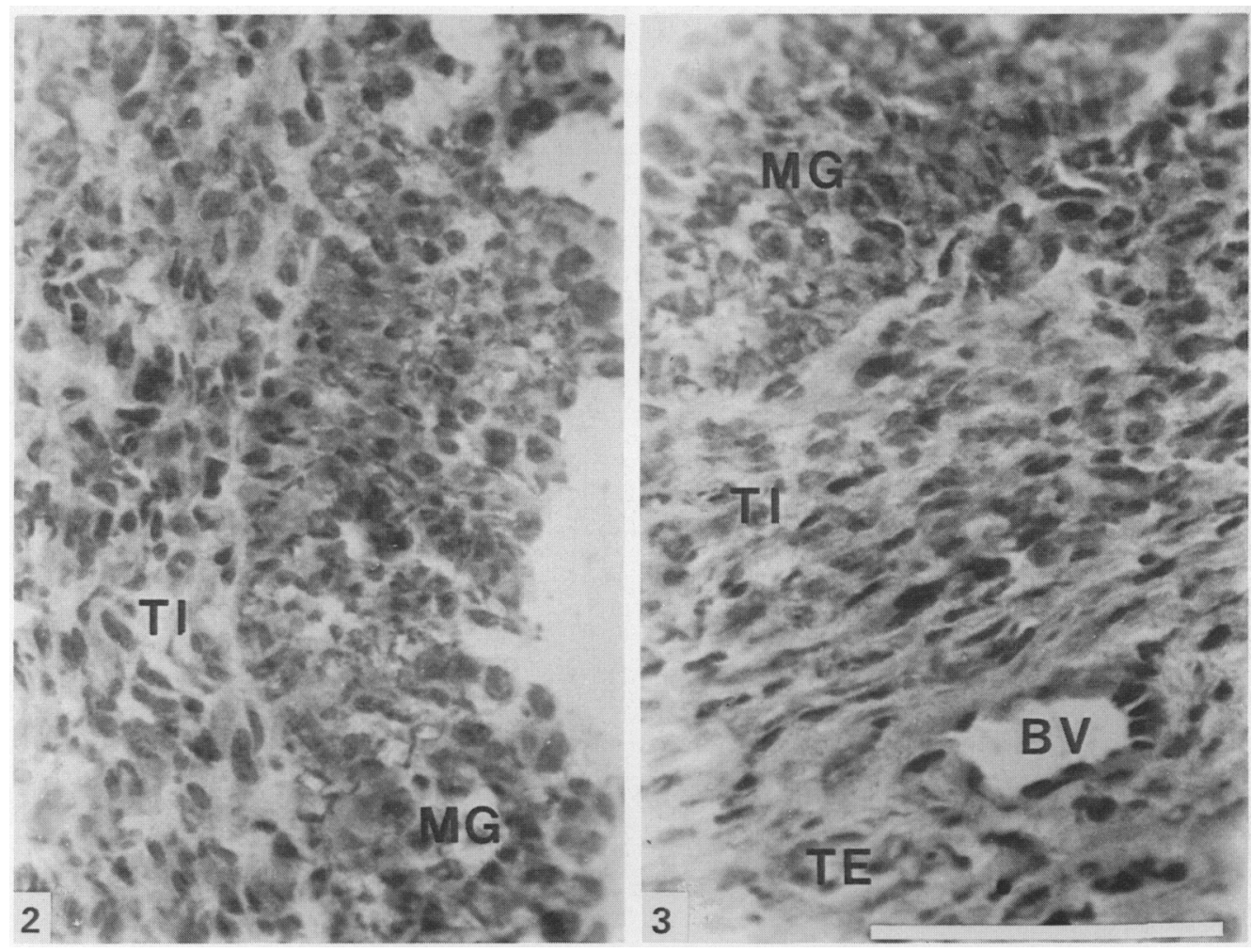

Figs 2 and 3. Light micrographs of follicle walls of follicles used in this study. TI, theca interna; $\mathrm{TE}$, theca externa; MG, membrana granulosa; $\mathrm{BV}$, blood vessel. $\mathrm{H} \& \mathrm{E}$, bar $=50 \mu \mathrm{m}$.

reticulum respectively, included the hilus, ovarian stroma, surface epithelium, and preantral and antral follicles, both atretic and healthy. Positive staining for these enzymes was detectable only in the walls of antral follicles in which theca layers and the membrana granulosa were differentiated. The cells of membrana granulosa were closely packed into an avascular layer (Figs 1-3), and both gap and adherens-type junctions were present between these cells. Moderate numbers of mitochondria and endoplasmic reticulum were found in the cytoplasm. The shape of the mitochondrial cristae was essentially lamellar and the endoplasmic reticulum was rough. In the theca interna layer the cells not associated with the vasculature were spindle-shaped and tended to be separated from each other by areas of extracellular matrix containing collagen fibrils. These cells were more rounded and less spindle-shaped than the very spindle-shaped fibrocytes (which were more numerous in the theca externa), and contained moderate numbers of mitochondria with essentially tubular/vesicular cristae and much endoplasmic reticulum, appearing predominantly rough.

Figures 2 and 3 show typical sections of follicle walls cut from O.C.T.-embedded material and used for immunostaining. When sections were cut from large follicles, the orientation of cells in the membrana granulosa was disrupted to a variable degree because of the formation of ice-crystals in follicular fluid. It was therefore not possible to distinguish easily healthy follicles from those that were in early atresia, as the diagnosis of this is usually made on the basis of the morphology of the membrana granulosa (Rajakoski, 1960; Marion et al., 1968). However, follicles could be classified as being in the advanced stages of atresia when the membrana granulosa was severely degenerate. 

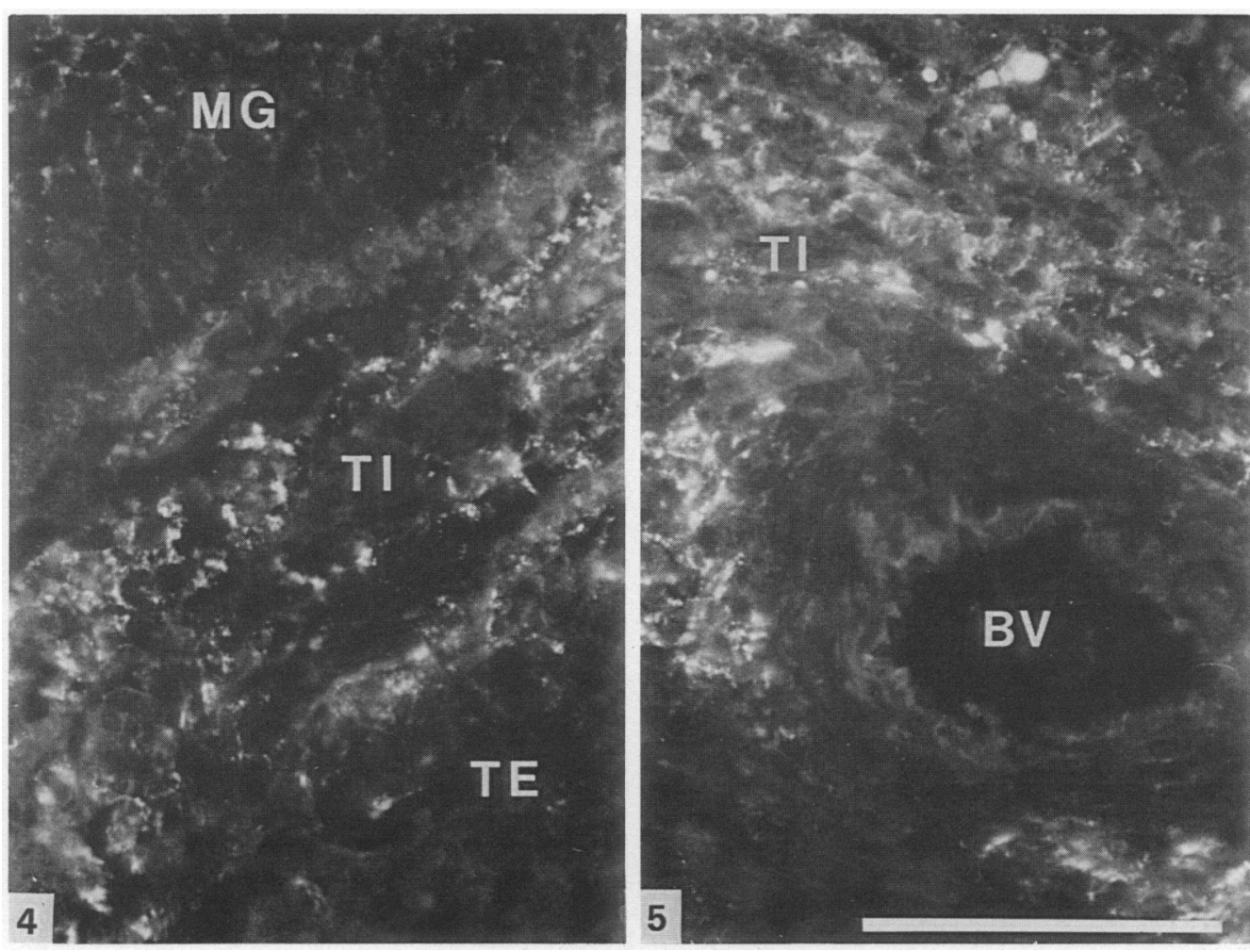

Figs 4-9. Light micrographs of immunofluorescence staining of follicle walls using anticytochrome $\mathrm{P}-450_{\text {scc }}$. Figure 8 shows the membrana granulosa of a large follicle from which follicular fluid was removed before freezing the follicle. Arrows indicate granulosa cells not staining as intensely as other granulosa cells. Fig. 4: large preantral follicle; Fig. 5: $3 \mathrm{~mm}$ follicle; Fig. 6: $4 \mathrm{~mm}$ follicle; Fig. 7: $6 \mathrm{~mm}$ follicle; Fig. 8: $15 \mathrm{~mm}$ punctured follicle; Fig. 9: $21 \mathrm{~mm}$ follicle. TI, theca interna; TE, theca externa; MG, membrana granulosa; BV, blood vessel. Bars $=50 \mu \mathrm{m}$.

\section{Immunofluorescent staining with anti-P-450 $\mathrm{scc} \operatorname{IgG}$}

Immunofluorescent staining of follicular walls with IgG against cytochrome P-450 scc $_{\text {is }}$ shown in Figs 4-9. No positive staining was observed in the theca externa but was observed in the theca interna and less intensely in the membrana granulosa. The immunofluorescent staining was punctate and localized to the cytoplasm (Fig. 7), indicative of a mitochondrial localization. In the theca interna, cells of the vasculature did not stain positively (Fig. 5), and judging from the pattern of staining it appeared that the less spindle-shaped cells, which had been observed by electron microscopy to have moderate numbers of mitochondria and tubular/vesicular cristae, were the positively staining cells. The theca interna of follicles in relatively advanced stages of atresia, in which the membrana granulosa was nearly absent, were observed to stain positively.

The cells of the membrana granulosa stained less intensely than the cells of the theca interna and in some instances it was only slightly more intense than that observed in sections with nonimmune IgG (Fig. 10). Generally, the staining of the membrana granulosa was more intense in the larger follicles. Within the membrana granulosa the distribution of staining appeared to be relatively even. However, in follicles in which the follicular fluid had been removed before embedding in O.C.T. compound, not all cells of the membrana granulosa stained to the same intensity (Fig. 8). 


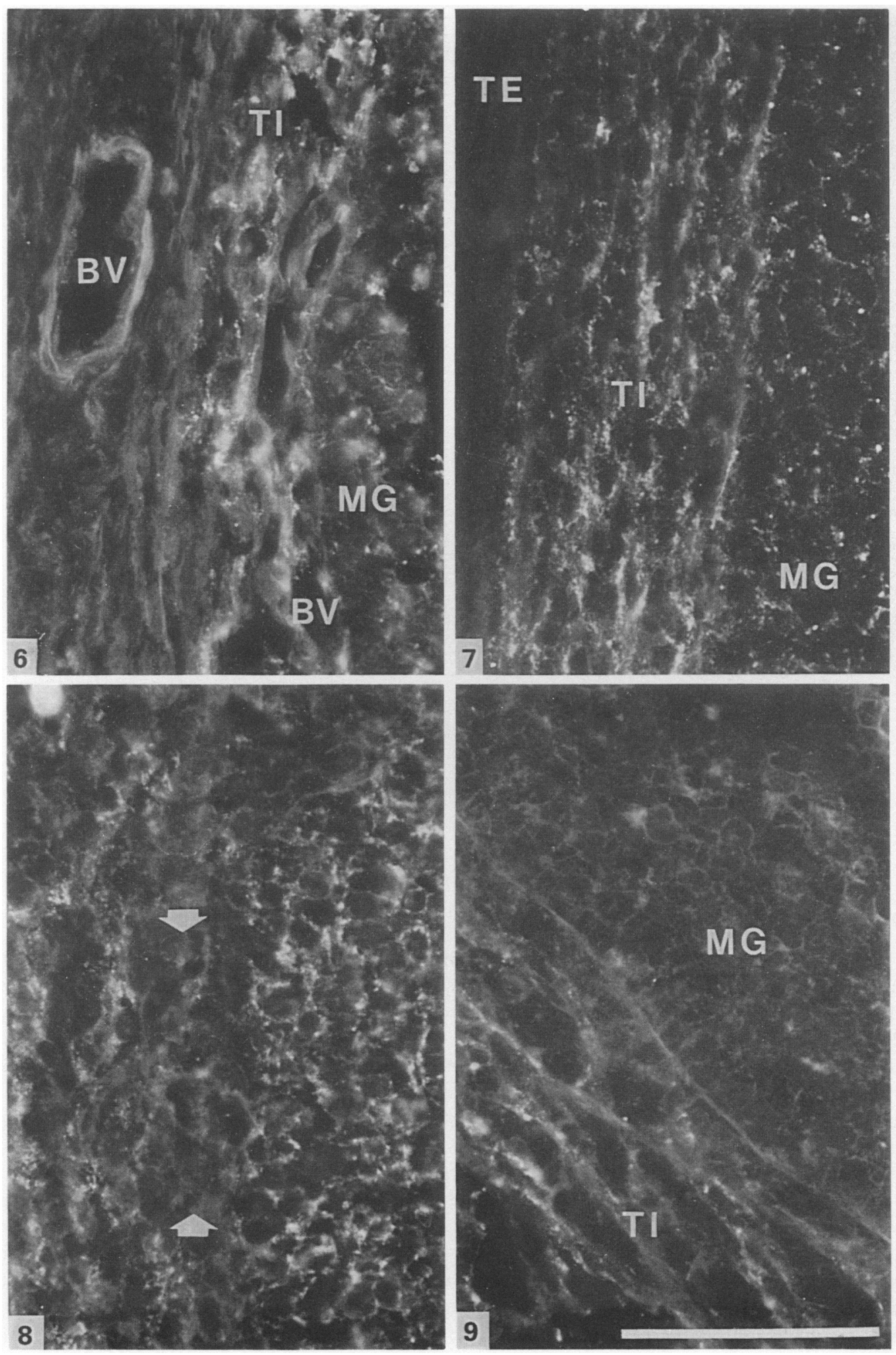



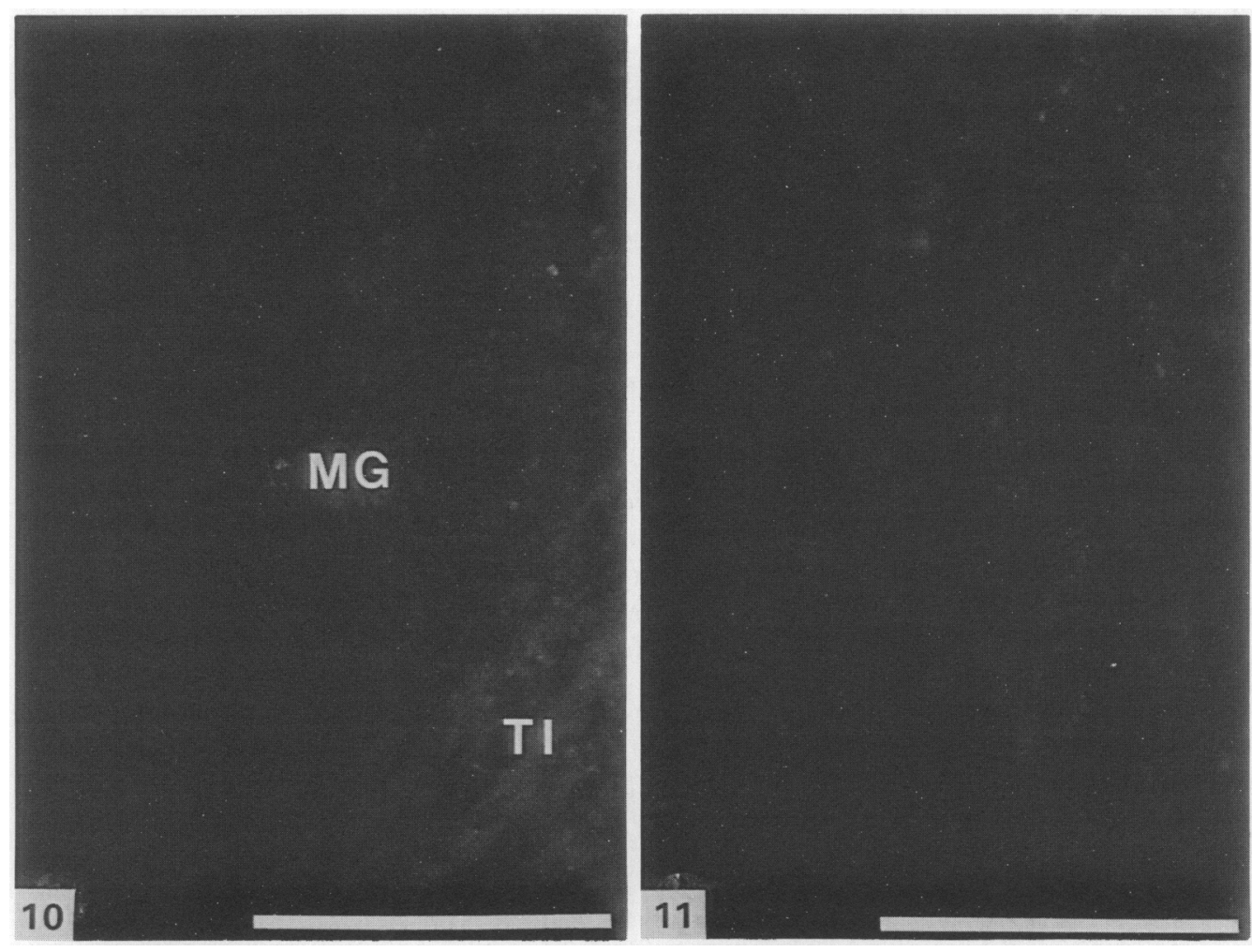

Fig. 10. Light micrograph of immunofluorescent staining of follicle wall using non-immune immunoglobulin (4 mm follicle). TI, theca interna; $M G$, membrana granulosa. Bar $=50 \mu \mathrm{m}$.

Fig. 11. Light micrograph of immunofluorescent staining of mature cyclic corpus luteum using anti-cytochrome $\mathrm{P}-450_{17 \alpha}$. Bar $=50 \mu \mathrm{m}$.

Immunofluorescent staining with anti-P-450 ${ }_{17 a} \mathrm{IgG}$

Ovarian tissues immunostained with IgG against cytochrome P-450 ${ }_{17 a}$ are shown in Figs $11-17$. Bovine corpora lutea did not stain positively for cytochrome P-450 $17 \alpha$ (Fig. 11), nor-did any other ovarian compartment other than the theca interna. Theca interna from healthy and severely atretic follicles stained positively for cytochrome P-450 ${ }_{17 a}$. The staining was localized to the cytoplasm and was relatively evenly distributed, suggestive of localization to the endoplasmic reticulum (Fig. 14). Blood vessels did not stain positively for cytochrome $\mathrm{P}-450_{17 a}$ and the pattern of staining in the theca was consistent with positive staining of the less spindle-shaped cells, the ones observed by electron microscopy to be rich in the endoplasmic reticulum.

\section{Discussion}

Steroidogenic properties of follicles have been studied in the past by a number of methods including (a) the measurement of steroids in follicular fluid (Merz et al., 1981; Ireland \& Roche, 1983), (b) the measurement of the specific tissue contents of steroidogenic enzymes (Rodgers et al., 1986a), (c) the in-vitro production of steroid hormones by follicles (Kruip et al., 1979) and follicle walls (McNatty 
et al., 1984a, b), and (d) the localization of steroidogenic enzymes by histochemistry (Rubin et al., 1963; Baillie et al., 1966) and microspectrometric analysis (Zoller \& Weisz, 1978).

From the present results, in which cytochromes $\mathrm{P}-450_{\mathrm{scc}}$ and $\mathrm{P}-450_{17_{\alpha}}$ were immunolocalized in bovine follicles, it was found that both enzymes were present in the cells of the theca interna at or near the time of its differentiation. These cells have endoplasmic reticulum, predominantly rough, and moderate numbers of mitochondria whose cristae were both lamellar and tubular. Cytochrome $\mathrm{P}-450_{\text {sce }}$ but not cytochrome $\mathrm{P}-450_{17 \mathrm{a}}$, was present in the granulosa cells of some antral follicles, and not all cells stained to the same intensity.

Progesterone is present in significant amounts and can be produced in vitro by bovine theca interna (Shemesh, 1979; McNatty et al., 1984b) and luteal tissues (Hansel et al., 1973; Gospodarowicz \& Gospodarowicz, 1972; Ursely \& Leymarie, 1979). In agreement with this in the present study cytochrome P-450 scc was found to be localized to the walls of follicles with differentiated theca, as well as cyclic corpora lutea (Rodgers et al., 1986b), although the intensity of the immunostaining was less in the cells of the follicles. In the theca interna, cytochrome P-450 $0_{\text {scc }}$ appeared to be localized to the less spindle-shaped cells, which by electron microscopy were seen to be rich in endoplasmic reticulum, predominantly rough, and to have moderate numbers of mitochondria with mainly tubular/vesicular cristae. The very spindle-shaped fibrocytes, which were predominant in the theca externa, were negative for the presence of cytochrome P-450 $0_{\text {scc }}$. Even in atretic follicles the cells of the theca interna were positive for the presence of cytochrome $\mathrm{P}-450_{\mathrm{scc}}$
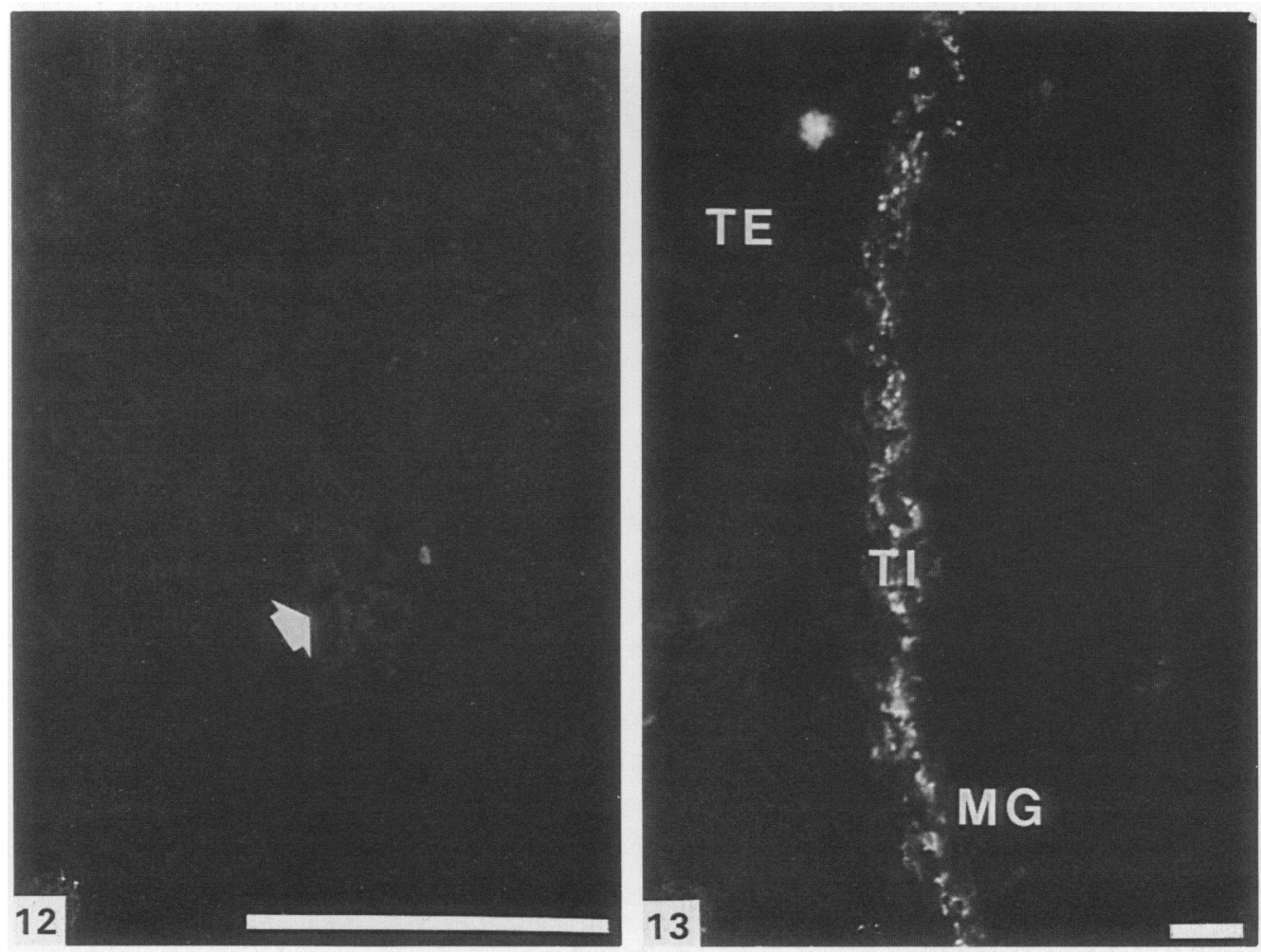

Figs 12-17. Light micrographs of immunofluorescent staining of follicle walls using anticytochrome P-450 ${ }_{17 \mathrm{a}}$. Fig. 12: a very small preantral follicle (arrows) with undifferentiated theca; Fig. 13: $4 \mathrm{~mm}$ follicle; Fig. 14: $4 \mathrm{~mm}$ follicle; Fig. 15: $6 \mathrm{~mm}$ follicle; Fig. 16: $12 \mathrm{~mm}$ follicle; Fig. 17: $21 \mathrm{~mm}$ atretic follicle. TI, theca interna; TE, theca externa; MG, membrana granulosa. Bars $=50 \mu \mathrm{m}$. 

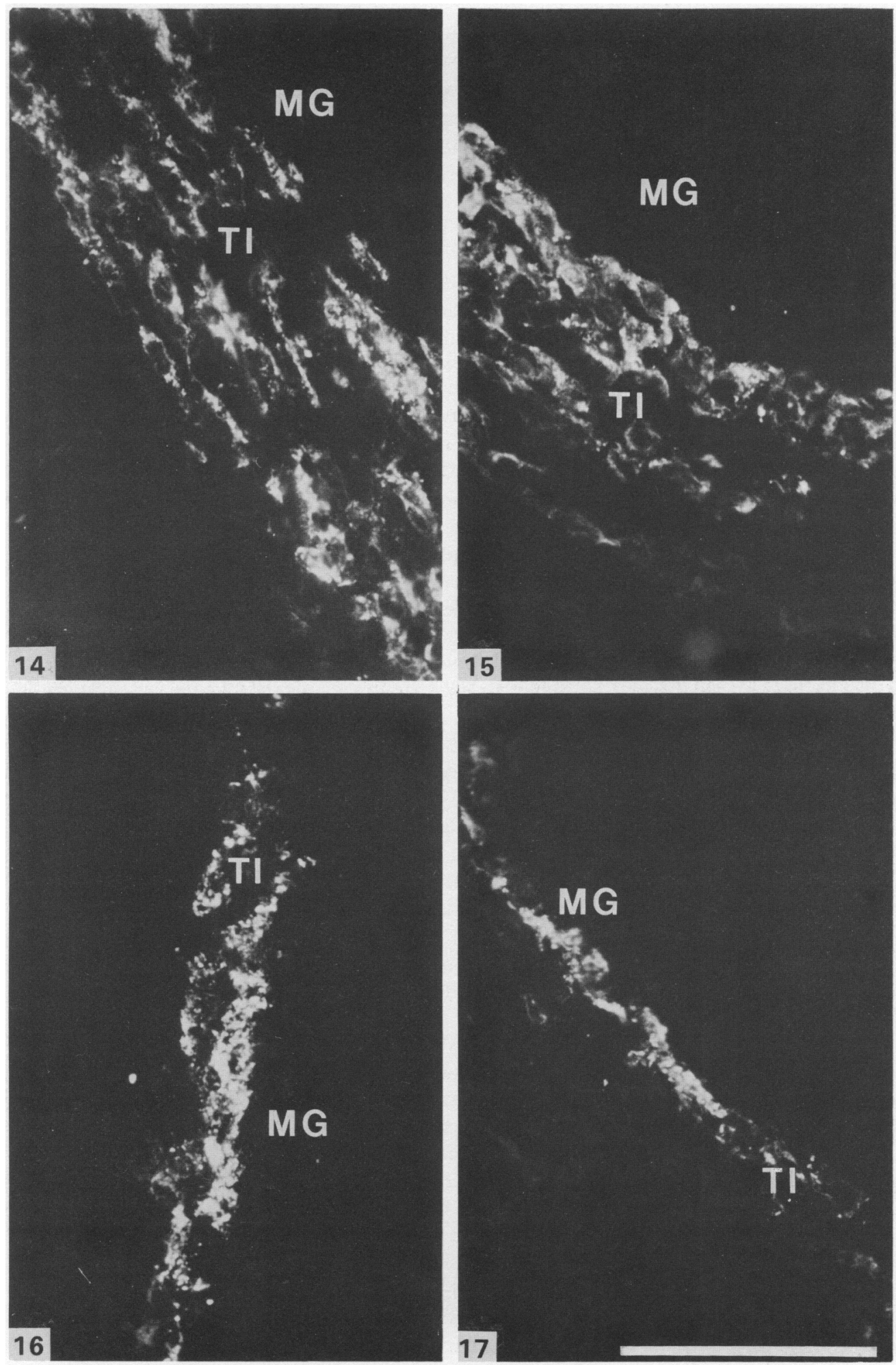
and although the theca interna of antral follicles has been shown not to respond to LH, it did produce progesterone and androgen in vitro in amounts similar to those of healthy follicles on a wet weight of tissue basis (McNatty et al., 1984b). The membrana granulosa in some follicles stained positively for cytochrome $\mathrm{P}-450_{\mathrm{scc}}$ although the intensity was less than that of the theca interna and in some follicles was barely above background. In general, the staining of the membrana granulosa was more intense in larger follicles. In agreement with these results it has been shown that bovine granulosa cells have measurable amounts of cytochrome P-450 $0_{\mathrm{scc}}$ (Funkenstein et al., 1983) and can produce progesterone in culture (Henderson \& Swanston, 1978; Henderson \& Moon, 1979; Shemesh, 1979). On the other hand, stroma and preantral follicles with undifferentiated theca did not stain positively for cytochrome $\mathrm{P}-450_{\text {scc }}$. Stromal tissue which in many studies includes small preantral follicles had a very low content of steroid and produced very little steroid in vitro (McNatty et al. , 1984b). There is therefore good agreement between the ability of a tissue to produce $\mathrm{C}_{21}$-steroids and its content of cytochrome $\mathrm{P}-450_{\text {scc }}$, and this suggests that one mechanism by which pregnenolone and progesterone production by the ovary is regulated could involve regulation of the cellular content of cytochrome P-450

The conversion of pregnenolone or progesterone into androgens is catalysed by the microsomal enzymes cytochrome $\mathrm{P}-450_{17 \alpha}$ and $\mathrm{C}_{17,20}$-lyase, which appear to be the same enzyme (Nakajin \& Hall, 1981; Kominami et al., 1982; Nakajin et al., 1984; Suhara et al., 1984). In the present study, cytochrome $\mathrm{P}-450_{17 a}$ was localized only to the theca interna and was not present in small preantral follicles, which did not have differentiated theca, or in any other ovarian compartment. In bovine ovaries it has been shown that only the theca interna contained and produced androgen in vitro (McNatty et al., 1984b). Bovine corpora lutea have barely detectable levels of microsomal cytochrome P-450 (McIntosh et al., 1971) and in vitro produced even under LH stimulation only small amounts of testosterone, equivalent to $<1 \%$ the amount of progesterone produced (Shemesh et al., 1975). No studies akin to localization of cytochrome $\mathrm{P}-450_{17 \alpha}$ have been reported except for the localization by microspectrophotometric analysis in rat ovaries of total cytochrome P-450, which in ovaries includes cytochromes $\mathrm{P}-450_{\text {scc }}$ and $\mathrm{P}-450_{17 \alpha}$ and aromatase cytochrome $\mathrm{P}-450$, to areas of the membrana granulosa (Zoller \& Weisz, 1978). In the present study cytochrome $\mathrm{P}-450_{17 \mathrm{a}}$ was present in atretic follicles whose theca produced androgen in vitro even though it was unresponsive to LH (McNatty et al., 1984b). These findings therefore suggest that the ovarian source of androgen, either secreted into the blood or converted into oestrogen, is the theca interna. Moreover given the close relationship between a tissue's ability to produce androgen and its content of cytochrome $\mathrm{P}-450_{17 \alpha}$, it is suggested that one mechanism by which androgen synthesis is regulated could involve the regulation of the cellular content of cytochrome $\mathrm{P}-450_{17 \mathrm{a}}$.

Ultrastructural studies of 'steroidogenic' cells have revealed these cells as having a high density of mitochondria with tubular cristae, and much smooth endoplasmic reticulum (Christensen \& Gillim, 1969). Neither cells of the theca interna nor membrana granulosa had a particularly high concentration of mitochondria, and the volume density of mitochondria has been reported to be less than that of large luteal cells (Priedkalns \& Weber, 1968a). The mitochondrial cristae of theca cells were more tubular than the more lamellar-shaped cristae of the granulosa cells and since the

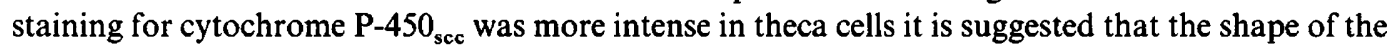
cristae is related, in part, to the content of this steroidogenic enzyme. The endoplasmic reticulum in the theca interna cells was extensive and predominantly rough. Priedkalns \& Weber (1968b) observed that the ratio of rough to smooth endoplasmic reticulum declined as oestrus approached and they related these changes to the acquisition of steroidogenic function by these cells. However, in the present study it was found that cytochrome $\mathrm{P}-450_{17 \alpha}$ was present even in very small follicles where the endoplasmic reticulum was predominantly rough. This suggests that attachment of ribosomes to endoplasmic reticulum per se is not related to steroidogenic function of the cell.

It has been postulated that in a number of species follicular oestrogen is produced by the aromatization in granulosa cells of androgens derived from the theca (see Hillier, 1981). The present data confirm for bovine follicles that oestrogen production by the granulosa cells requires 
androgen from cells of the theca interna since cytochrome P-450 ${ }_{17 \alpha}$ was only detectable in theca interna cells. However, to confirm or otherwise test the two-cell hypothesis, aromatase cytochrome P-450 needs also to be localized. Only then when all three key regulatory enzymes of the steroid production pathway have been localized will it be possible to determine if two different cell types are required for oestrogen production.

In conclusion, the findings of the current experiments strengthen the proposition that the amounts and types of steroid hormones produced by ovarian compartments are principally a reflection of the amounts and types of steroidogenic enzymes present. We suggest that regulation of ovarian steroidogenesis involves regulation of the synthesis and concentration of these steroidogenic enzymes.

We thank Dr J. M. Snyder for provision of histological facilities; Starlette Hollingsworth for typing the manuscript; the NIH for financial assistance (grants (HD-13234, AM-28350, HD-11149); and the Chilton Foundation for a grant-in-aid to R.J.R.

\section{References}

Baillie, A.H., Ferguson, M.M. \& Hart, D.McK. (1966) Developments in Steroid Histochemistry. Academic Press, London.

Christensen, A.K. \& Gillim, S.W. (1969) The correlation of fine structure and function in steroid secreting cells, with emphasis on those of the gonads. In The Gonads, pp. 415-488. Ed. K. W. McKerns. North Holland Publishing Co., Amsterdam.

DuBois, R.N., Simpson, E.R., Tuckey, J., Lambeth, J.D. \& Waterman, M.R. (1981) Evidence for a higher molecular weight precursor of cholesterol side-chaincleavage cytochrome P-450 and induction of mitochondrial and cytosolic proteins by corticotropin in adult bovine adrenal cells. Proc. natn. Acad. Sci. U.S.A. 78, 1028-1032.

Funkenstein, B., Waterman, M.R., Masters, B.S.S. \& Simpson, E.R. (1983) Evidence for the presence of cholesterol side chain cleavage cytochrome P-450 and adrenodoxin in fresh granulosa cells. Effects of follicle-stimulating hormone and cyclic AMP on cholesterol side chain cleavage cytochrome P-450 synthesis and activity. J. biol. Chem. 258, 10187-10191.

Gospodarowicz, D. \& Gospodarowicz, F. (1972). A technique for the isolation of bovine luteal cells and its application to metabolic studies of luteal cells in vitro. Endocrinology 90, 1427-1434.

Hansel, W. \& Convey, E.M. (1983) Physiology of the estrous cycle. J. Anim. Sci. 57, Suppl. 2, 404423.

Hansel, W., Concannon, P.W. \& Lukaszewska, J.H. (1973) Corpora lutea of large domestic animals. Biol. Reprod. 8, 222-245.

Henderson, K.M. \& Swanston, I.A. (1978) Androgen aromatization by luteinized bovine granulosa cells in tissue culture. J. Reprod. Fert. 52, 131-134.

Henderson, K.M. \& Moon, Y.S. (1979) Luteinization of bovine granulosa cells and corpus luteum formation associated with loss of androgen aromatizing ability. J. Reprod. Fert. 56, 89-97.

Hillier, S.G. (1981) Regulation of follicular oestrogen biosynthesis: a survey of current concepts. $J$. Endocr. 89, 3P-18P.
Ireland, J.J. \& Roche, J.F. (1983) Development of nonovulatory antral follicles in heifers: changes in steroids in follicular fluid and receptors for gonadotropins. Endocrinology 112, 150-156.

Kominami, S., Shinzawa, K. \& Takemori, S. (1982) Purification and some properties of cytochrome P-450 specific for steroid $17 \alpha$-hydroxylation and $\mathrm{C}_{17}-\mathrm{C}_{20}$ bond cleavage from guinea-pig adrenal microsomes. Biochem. Biophys. Res. Commun. 109, 916-921.

Kruip, Th.A.M., Dieleman, S.J. \& Moor, R.M. (1979) Steroid production by bovine follicles in vitro: influence of size, stage of cycle and culture sytem. Annls Biol. anim. Biochim. Biophys. 19, 1537-1545.

Marion, G.B., Gier. H.T. \& Choudary, J.B. (1968) Micromorphology of the bovine ovarian follicular system. J. Anim. Sci. 27, 451-465.

McIntosh, E.N., Uzgiris, V.I., Alonso, C. \& Salhanick, H.A. (1971) Spectral properties, respiratory activity, and enzyme systems of bovine corpus luteum mitochondria. Biochemistry, N.Y. 10, 2909-2916.

McNatty, K.P., Heath, D.A., Henderson, K.M., Lun, S., Hurst, P.R., Ellis, L.M., Montgomery, G.W., Morrison, L. \& Thurley, D.C. (1984a) Some aspects of thecal and granulosa cell function during follicular development in the bovine ovary. J. Reprod. Fert. 72, 39-53.

McNatty, K.P., Heath, D.A., Lun, S., Fannin, J.M., McDiarmid, J.M. \& Henderson, K.M. (1984b) Steroidogenesis by bovine theca interna in an in vitro perifusion system. Biol. Reprod. 30, 159-170.

Merz, E.A., Hauser, E.R. \& England, B.G. (1981) Ovarian function in the cycling cow: relationship between gonadotropin binding to theca and granulosa and steroidogenesis in individual follicles. $J$. Anim. Sci. 52, 1457-1468.

Nakajin, S. \& Hall, P.F. (1981) Microsomal cytochrome P-450 from neonatal pig testis. Purification and properties of a $C_{21}$ steroid side-chain cleavage system (17a-hydroxylase-C $\mathrm{C}_{17,21}$ lyase). J. biol. Chem. 256, $3871-3876$.

Nakajin, S., Shinoda, M., Haniu, M., Shively, J.E. \& Hall, P.F. (1984) $C_{21}$ steroid side chain cleavage enzyme 
from porcine adrenal microsomes. Purification and characterization of the $17 \alpha$-hydroxylase $/ \mathrm{C}_{17.20^{-1}}$-lyase cytochrome P-450. J. biol. Chem. 259, 3971-3976.

Priedkalns, J. \& Weber, A.F. (1968a) Ultrastructural studies of the bovine Graafian follicle and corpus luteum. Z. Zellforsch. mikrosk. Anat. 91, 554-573.

Priedkalns, J. \& Weber, A.F. (1968b) Quantitative ultrastructural analysis of the follicular and luteal cells of the bovine ovary. Z. Zellforsch. mikrosk. Anat. 91, 574-585.

Rajakoski, E (1960) The ovarian follicular system in sexually mature heifers with special reference to seasonal, cyclical and left-right variations. Acta endocr. Copenh., Suppl. 52, 3-68.

Rodgers, R.J., Waterman, M.R. \& Simpson, E.R. (1968a) Cytochromes P-450 sec, $\mathrm{P}-450_{17 \alpha}$, adrenodoxin and reduced nicotinamide adenine dinucleotide phosphate-cytochrome $\mathrm{P}-450$ reductase in bovine follicles and corpora lutea. Changes in specific contents during the ovarian cycle. Endocrinology 118, 1366-1374.

Rodgers, R.J., Rodgers, H.F., Waterman, M.R. \& Simpson, E.R. (1986b) Immunolocalization of cholesterol side-chain-cleavage cytochrome P-450 and ultrastructural studies of bovine corpora lutea. $J$. Reprod. Fert. 78, 639652.

Rubin, B.L., Deane, H.W. \& Hamilton, J.A. (1963) Biochemical and histochemical studies on $\Delta^{5} 3 \beta$ hydroxysteroid dehydrogenase activity in adrenal glands and ovaries of diverse mammals. Endocrinology 73, 748-763.
Seybert, D.W., Lancaster, J.R., Jr, Lambeth, J.D. \& Kamin, H. (1979) Participation of the membrane in the side chain cleavage of cholesterol. Reconstitution of cytochrome P-450 scc into phospholipid vesicles. $J$. biol. Chem. 254, 12088-12098.

shemesh, M. (1979) Inhibitory action of follicular fluid on progesterone and prostaglandin synthesis in bovine follicles. $J$. Endocr. 82, $27-31$.

Shemesh, M., Hansel, W. \& Concannon, P.W. (1975) Testosterone synthesis in the bovine corpus luteum. Biol. Reprod. 13, 490-493.

Suhara, K., Fujimura, Y., Shiroo, M. \& Katagiri, M. (1984) Multiple catalytic properties of the purified and reconstituted cytochrome P-450 (P-450 system of pig testis microsomes. J. biol. Chem. 259, 8729-8736.

Ursely, J. \& Leymarie, P. (1979) Varying responses to luteinizing hormone of two luteal cell types isolated from bovine corpus luteum. J. Endocr. 83, 303-310.

Zoller, L.C. \& Weisz, J. (1978) Identification of cytochrome P-450, and its distribution in the membrana granulosa of the preovulatory follicle, using quantitative cytochemistry. Endocrinology 103, 310-313.

Received 2 April 1986 